\title{
ПОНЯТТЯ \\ «ВЕЛИКА ЛІТЕРАТУРА» І «МАСОВА ЛІТЕРАТУРА» В ЛІТЕРАТУРНО-КРИТИЧНІЙ СПАДЩИНІ УЛАСА САМЧУКА
}

У статті на матеріалі маловідомої літературно-критичної та публіиистичної прози У. Самчука авторка розглядає його естетичні погляди, значення понять «велика література» й «масова література» в естетичній концепціі письменника. Авторка довела, щуо у своӥх прачях великій літературі (класииі) У. Самчук протиставляв масову літературу, яскравим зразком якої вважав твори сочіалістичного реалізму.

Ключові слова: велика література, масова література, естетична концепція.

В статье на материале малоизвестной литературно-критической и публицистической прозы У. Самчука автор рассматривает его эстетические взглядbl, значение понятий «великая литература» и «массовая литература» в эстетической концепции писателя. Автор доказал, что в своих трудах великой литературе (классике) У. Самчук противопоставил массовую литературу, ярким примером которой считал произведения социиалистического реализма.

Ключевые слова: великая литература, массовая литература, эстетическая концепция.

In the article according to Ulas Samchuk's little known literary-critical and publicistic prose, the author examines his aesthetic views, the meaning of the notions great literature and mass literature in the writer's aesthetic conception. The author proved that Ulas Samchuk in his works opposed great literature (classical literature) to mass literature, the magnificent example of which he considered to be the works of socialistic realism.

Keywords: great literature, popular literature, aesthetic category.

Своє призначення художні твори виконують по-різному, а іноді й зовсім ухиляються від нього. У зв’язку з цим прийнято говорити про такі поняття, як «висока література», «белетристика» і «масова література». Чіткість розмежування названих феноменів 
у сучасному літературознавстві відсутня. Поняття літературного «верху» й «низу» породжують різні суперечки, однак спроби упорядкування літературних фактів у певні ієрархії з'являються постійно.

Широковживане словосполучення «висока література» не має смислової визначеності, однак є логічним виділенням з усієї літературної маси тієї їі частини, яка заслуговує на увагу і яка виконує своє культурно-художнє призначення. Вершину цієї літератури прийнято називати «класикою» - тим пластом художньої словесності, яка цікава й авторитетна для цілого ряду поколінь; це золотий фонд літератури.

В історії української літератури був особливо важливий період, коли поняття класики набуло статусу програмового і перетворилося на основний чинник культурного життя української еміграції. Йдеться про другу половину 40-х років ХХ століття епоху Мистецького Українського Руху (МУР) і поняття «велика література», що набуло особливого змісту в однойменному виступі У. Самчука на Першому з'їзі МУРу (1945).

Резонанс висунутого постулату був досить великим як у часи його появи, так і в пізнішу добу. Серед сучасників У. Самчук мав і прихильників, і опонентів. Однак уже у 80-90-х роках поняття великої літератури стало об’єктом нищівної критики Г. Грабовича (спочатку це була стаття «Велика література» в журналі «Сучасність» (1986), пізніше - більш розлога розвідка «У пошуках великої літератури» (1993)), до якої за своїми тональностями і позицією долучилася і С. Павличко в «Дискурсі модернізму в українській літературі» (1997). Американський дослідник, категорично обмежуючи літературу виключно естетичними повинностями, звульгаризував ідею У. Самчука і висловив низку агресивних думок щодо неї. Подекуди його розмисли супроводжує ядуча іронія: «...ясна річ, ще ніколи перед тим, як і ніколи пізніше, украӥнську літературу не визначала така великість» [Грабович 1993: 19].

Не менш різкою була критика С. Павличко, яка все-таки відчула основні акценти доповіді: У. Самчук «висунув конщепщію лі- 
тератури універсального значення й змісту, яка була б найвищим виявом душі народу, його мислення, підсумком його історії, а водночас виявом цілого людського духу»; «велика література - серйозна, класична, універсальна за своїм значенням та впливом»; «велика література є канонічною літературою. Взірием для Самчука залишається класична спадщина» [Павличко 1997: 246]. Однак висновок дослідниці дивує: «3а своїми естетичними поглядами та вимогами Улас Самчук традиціоналіст і людина попереднього століття» [Павличко 1997: 246]; «його рецепт увійти до світової літератури, щуо називався "великою літературою", означав імітацүію чи реставрацію певного класичного стилю (на кшталт Гете)» [Павличко 1997: 247]. А насамкінець авторка наведених тез категорично оцінила постулат митця: «Висуваючи гасло "великої літератури", Самчук певною мірою передбачав, щчо начіональний реалізм його епопей стане ї̈ зразком» [Павличко 1997: 249].

За своїми переконаннями У. Самчук був консерватором і традиціоналістом, котрий орієнтувався на ангажовану національною ідеєю літературу. Україна для письменника залишалася радше духовною, аніж реально існуючою фізичною інстанцією. Народ, на його думку, будував свою незалежність тільки і виключно Словом [Самчук 1946: 132]. У таких умовах на літературу покладалися, крім основних, інші, неестетичні повинності. Передусім вона мала виконувати пізнавальну функцію, бо тільки «через слово, мову, літературу, як через призму світло, проходить і розкладається на безліч відтінків людська думка, якої завданням є висловити повноmy, изілість об'єкта, з якого вона походить» [Самчук 1971: 4]. У. Самчук висловив переконання, що вся увага митця, як і філософа, має бути зосереджена на вивченні «людини, людей, народу, народів, пізнанні їх призначення, їх функиій, їх долі» [Самчук 1971: 6]. Теза «пізнай самого себе» лишається для них актуальною від часів Сократа. Зосереджуючись на «дії пізнавання» як визначальній місії літератури, письменник назвав знакові твори європейських класиків, які намагалися збагнути дух своєї нації, «психологію 
раси», а в тому - суть певних законів життя в їх першопочатках, законів переважно універсального, вселюдського значення. Серед них - «Божественна комедія» А. Данте, «Фауст» Й. В. Гете, «Гамлет» В. Шекспіра, «Мертві душі» М. Гоголя, «Брати Карамазови» Ф. Достоєвського, «Сага про Форсайтів» Д. Голсуорсі, «Благословенство землі» К. Гамсуна, «Селяни» В. Реймонта, «Будденброки» Т. Манна. Кожен з названих прозаїків на естетичному рівні «висловив свою расу, свій народ і свою державність» [Самчук 1971: 9]. Ці міркування, висловлені У. Самчуком наприкінці лютого 1971 року у виступі перед студентами Оттавського університету, засвідчили, що письменник не відмовився від уявлень про літературу як один 3 найважливіших факторів духового самовияву нації, сформульованих ним ще у період МУРу.

Великі твори, стверджував письменник у повоєнний період, надають народам «право бути висловленими, бути не німими», «кожна літера $i$ кожний знак висловить нас учинно $i$ тривало» [Самчук 2005: 15, 28]. У цьому випадку поняття «велика література» варто сприймати як синонім до словосполучення «класична література», що неодмінно пов'язувалася У. Самчуком 3 автентичною творчістю, яка відбивала форму і зміст якоїсь конкретної нації. До речі, у такому ж значенні вживав цей термін і Д. Чижевський у німецькомовній праці «Порівняльна історія слов'янських літератур» (1968) [Чижевський 2005: 188]. При цьому постать художника слова вважалася вагомою, оскільки «письменник $i$ нація $\epsilon$ одна суть. Вони лише тоді справжні, коли себе взаӥмно висловлюють» [Самчук б. д.-1: 2].

У цих роздумах У. Самчука простежується вісниківське розуміння категорії національності, яка, універсалізувавшись, виступає стимулом художньої творчості. 3 цього приводу варто нагадати думки про «расову відповідальність», «служіння расі» Ю. Липи («Бій за українську літературу») і тезу «мистецька творчість <... викриває в творі <..> найглибше - расу» Є. Маланюка («Книга спостережень»). Твори «великої літератури» забезпечують тяглість 
етносу в часопросторі, міцний зв’язок між давніми епохами і сьогоденням. Народи, які спромоглися дати світові зразкові мистецькі витвори, стали великими і творчими народами. Для прикладу У. Самчук побіжно охарактеризував основи буття англосаксонського світу. Підмурівком його існування на одному місці впродовж віків були чітка організація державних, національних, соціальних форм життя і тривала узвичаєність. Традиційна європейська культура приховувала в собі надійні орієнтири, що підтримували життєву потугу нації, дух безнастанного поступу на шляху вдосконалення. Ïї чільному представникові В. Шекспіру вдалося висловити свою расу і писаним словом створити «документ з правом на вічність» [Самчук 2005: 15]. У німців це зробив Й. В. Гете. Його найближчим учнем на українському грунті У. Самчук вважав I. Франка, який гартував духове єство нації, плекав людей великої душі і глибокої натури. Його твори належать до літератури, насиченої вищими правдами і вольовими чинниками, тобто до «великої літератури». Але досить відчутний брак культури вищого ступеня, на думку мисленника, все-таки гальмував поступ українців, декларована потреба «пізнавання себе» втілювалася повільно. Душезнавцем української людини він називав М. Гоголя. У героях «Вечорів на хуторі біля Диканьки» чи «Тараса Бульби» читач міг побачити й відчути себе в найрізноманітніших фізичних і психологічних істотностях. Глибину і точність спостережень автора згаданих творів У. Самчук назвав перфектними, тобто досконалими.

Дослідник підкреслив не тільки етнічне походження письменника, а й українську тематику й українську стихію в його творчості, закоріненість останньої в потужних пластах фольклору, адже навіть побут тут висловлено мовою народних загадок, легенд і символів. У. Самчук закцентував на особливості мовної палітри російського митця, оскільки своє дослідження української людини той виклав не рідним словом, а «сильно сполтавщеним діялектом Петербурга» [Самчук 1971: 11]. Не можу стверджувати категорично, що мисленнику вдалося віднайти методологічний «ключ розу- 
міння» гоголівського варіанту російської літературної мови (про відсутність такого в дослідженнях українських еміграційних критиків писав Ю. Барабаш [Барабаш 2004: 96]), однак у цитованій тезі проступає розуміння У. Самчуком двоїстості названого феномена. Його проникливість у поглядах на значення постаті М. Гоголя для української культури подиву гідна, оскільки в еміграційних інтерпретаціях осмислення спадщини російського митця відбувалося в межах дихотомічної пари «наш» (Д. Донцов) «не наш» (Ю. Липа) з виразним наголосом на феномені малоросійства, окресленого формулою «Гоголь - Гоголь» (С. Маланюк). Позиція У.Самчука спонукає до інших висновків. В істориколітературному вимірі творчість М. Гоголя, попри іiі російськомовність, багатьма своїми особливостями (поміж ними й мовними) закорінена в українську літературну традицію, на рівні культурному вона являє собою російськомовне відгалуження української культури, випадок виявлення засобами чужої мови свого національного єства, ментальних особливостей української людини та іiі духовного світу. Про це пишуть і сучасні гоголезнавці [Барабаш 2004: 100].

До справи пізнання української людини в іiі часі та іiі просторі долучилися, на думку У. Самчука, І. Котляревський, Т. Шевченко, П. Куліш, Леся Українка, І. Франко, але українська літературна вражала критика певною однобічністю. Філософські проблеми висвітлювалися переважно мовою поезії з ії ліричною, досить чуттєвою концепцією дійсності, де все зводилося до фокусу емоцій, болю, співчуття, жалю, а рушійною силою вважалися доля, визначення, приречення. Сенсуальне наставлення витворило досить тенденційну концепцію філософії Добра і Зла, за якою крилися культ малих, убогих і погорда до всього великого, багатого. Усе вбоге і немічне - добре, сильне і багате - зле. Петро і Наталка («Наталка Полтавка» I. Котляревського) - добрі, чесні, гарні, натомість їхні супротивники - злі, нечесні, погані. Такий поділ соціальних чеснот перетворився, переконаний митець, на основну моральну 
засаду української літератури, яка плекала нехіть і відразу до людини активної, творчої та здобуваючої.

Названу вище дихотомічну пару доповнює й інша: «село місто». Перше було об'єктом поневолення, друге - квінтесенцією зла. Так, У. Самчук нагадує, що в Т. Шевченка місцем, «де серце відпочине», є село, бо воно «наше», «українське», а місто «німецьке, або турецьке, а може то московське». У. Самчук, світовідчуття якого було типово європейським, наголошує, що маємо справу не 3 категоріями «своє - чуже», а 3 духовим наставленням, моральною вартістю: «Це вислів ідеалу, за яким має формуватися моє Его, Я, а тим самим моє сочуіальне, політичне і господарське Кредо, тобто вірування. Загально ие вислів конщепції нашої людини» [Самчук 1971: 14]. Ідеалом письменника була «сильна», «активна», «творча», «заможна», «ділова» особистість, вона й стала головним героєм його художньої прози. Певну «життєву дерзость» цій людині «дає місто своїми обріями, закованими в лінію будівлі, і своӥм зенітом величезного буяння фантазії. Сама проекція міста провокує уяву, $i$ тоді розум і логіка мусять діяти» [Самчук б. д.-2: 36].

3 твердження У. Самчука про літературу як один з факторів духового самовияву нації витікає інше: «Література - це мова народу» [Самчук 2005: 11]. Простежимо за окремими розмислами письменника. Слово - це думка, а думка - рушій усього людського. Раз колись посіяне, воно переходить у чин, і від цього значною мірою залежатиме, яке місце буде відведене тій чи тій нації на планеті Земля. Завдяки мові кожна з них має можливість бути історичною: «Це є також одна з основних засад життя $і$ на цій засаді були побудовані на землі держави, їх закони, їх культури, як також їх історія. Кожний циивілізований народ виходить від кореня своєї мови і своєї літератури» [Самчук 1971: 4]. Убити мову - означає убити народ. Мова «великої літератури» служить засобом порозуміння між народами. Своєю внутрішньою динамікою, силою духу і героїкою чину вона зрозуміла кожній людині незалежно від іiї національної приналежності. Писане слово завжди стоїть на сторожі 
національного буття. Народ України, починаючи від І. Котляревського і закінчуючи актом 22 січня 1918 року, будував свою незалежність Словом, яке стало ознакою не мистецьких виявів, а політичного бажання. Думається, у твердженні про внутрішню подібність окремих думок митця з положеннями новітніх філософських систем, зокрема літературної герменевтики, штучного «протягування за вуха» немає. Не такий уже й анахронічний український мисленник, як це може видатися на перший погляд, хоча за своїми симпатіями він усе-таки адепт традиціоналізму.

У. Самчук вважав, що після Першої світової війни й визвольних змагань 1917-1921 pp. українська література повинна була змінити весь курс свого спрямування, оскільки на кін національної історії виступила вимога формувати в української людини національне, державницьке мислення. Уже на переломі XIX i XX століть Леся Українка, М. Коцюбинський, І. Франко, О. Кобилянська, В. Винниченко зробили в цьому напрямі чимало, але їхнє філософське, ідеологічне наставлення митець трактував як матеріалістичнораціоналістичне. У нових умовах забракло самих лишень соціальних, етнографічних і навіть естетичних аспектів. Література потребувала психології та філософії, тобто нових основ духу. І це сталося після української революції. Цитуючи раннього П. Тичину, він зазначав, що в поезії «Не Зевс, не Пан...» (збірка «Сонячні кларнети») зображене пробудження людської свідомості зі спрямуванням у далекі часові, просторові та духовні обшири глобального космічного засягу.

20-30-ті роки були для У. Самчука часом напруженого змагання 3 «побутовницькою» атмосферою в українській літературі, часом «ренесансу духової літературної суті, ие був період розгортання обріїв країни поза границі українського світу як географічного, так і духового» [Самчук 1971: 20]. Незважаючи на моду всіляких «ізмів» та мистецьких течій, література стала «динамічною, дерзкою, настирливою, < ..> появилися вимагаючі люди, як от хоч би Донцуов у публіцистиці, як ранній Тичина, як Маланюк, як Хви- 
льовий... Появився роман з назвою "Місто" Підмогильного, заговорила величезна група неокласиків на східньому фронті України, появився Юрій Липа і ціла група так званих вісниківців на заході» [Самчук 1971: 21]. У цьому мажорному піднесенні почав відновлювати свої життєві сили український роман: «Чотири шаблі» Ю. Яновського, «Мати», «Бур'ян» А. Головка. Проза для У. Самчука була ознакою спотужнення, організації почуттів, незалежного ідейного спрямування. Навіть 3 ярликом «пролетарська» українська література, незважаючи на відсутність можливостей акцентувати на національному, мала шанс вирватися зі свого «вікового стагнаціийного вегетування», «тим більще, щуо у нас був тоді щзе "захід", Львів, Прага» [Самчук 1971: 22], тобто той культурний простір, до якого письменник залучав і себе. Компенсуючи деструкційні явища в політичному й духовному житті, література мала формувати націю духово, позначатися на іï способах, змістах мислення та сприйняття впродовж тривалого часу.

«Великій літературі» У. Самчук протиставляв літературу «до кишені». В американській культурі такою для нього була дешева криміналістика, що продукувалася спеціальними фабриками, мала доволі сумнівну якість і була розрахована на читача, не залученого або мало залученого до художньої культури, невибагливого, який не мав розвинутого смаку і не бажав мислити самостійно й належно оцінювати твори, який шукав у друкованій продукції тільки розваг. Уже 1943 року в статті «Щось, чи що читати», що була надрукована в газеті «Волинь», письменник зазначав: «Романи "до кишені" масово $і$ дешево продукувалися спеціальними фабриками романів і продавались у кіосках, мов часописи. Читачі, особливо молодь, ковтали їх, сидячи в трамваї, чи потязі, чи очікуючи на початок гри на грищі футболу. Сьогодні бачимо висновок з того. Безліч нервових, зістеризованих і тупоумних типів, які впливають на хід иілого життя» [Самчук 1943-2: 342].

У. Самчук розумів, що «масова література» приносить у сферу культури виразний вимір «політики». Маскультура як ім- 
перський проект деконструює високу національну. Масова література як суто імперське явище стає засобом деконструкції духовності нації, що зумовлює хаос. Не випадково в сучасній західній науці синонімом до цього поняття $\epsilon$ слово «анархія». Яскравим зразком «масової літератури» в колишньому СССР митець вважав твори соціалістичного реалізму: «Там знов поволі, але послідовно $і$ вперто отуплювали людину іншого роду. Не було книжки, починаючи "Дванадиятьома кріслами" Ільфа і кінчаючи підручником "Траленіє в Балтійском морє" Кірєєва, де не було б Маркса, марксизму, Леніна, ленінізму, Сталіна, сталінізму» [Самчук 1943-2: 342-343]. Митець констатував негативний вплив такого чтива на людину: «...сьогодні багато совєтських мозків поробились так твердими, а душі так розм'яклими, щуо іноді тяжко встановити границюю між людиною та молюскою» [Самчук 1943-2: 343].

Ведучи діалог із читачами «Волині», письменник велику надію покладав на них самих, навчав їх, як правильно обирати лектуру, що стала справжньою духовною поживою для реципієнта: «Важніше розбиратися у них (мова йде про літературні типи - I. P.) $i$ вибирати, старанно і свідомо розрізняючи, де те, щуо творить та родить, і те, щзо так непомітно, але певно розкладає і вбиває...» [Самчук 1943-1: 345].

Отже, у літературно-критичних працях У.Самчук зробив спробу створити свою філософію культури й мистецтва, яка, з одного боку, формувала б митця, його розуміння навколишнього світу, а з іншого, - передбачала глибоке пізнання індивідуальності українського народу, його ментальності, історичних і творчих коренів. «Велика література» була для нього вираженим у слові світом людських емоцій, тому вона й належить до загальнокультурних явищ. Її варто розглядати за своєрідністю тієї культурної спільноти, з якої виріс митець, а нею для У. Самчука була нація.

Естетику української літератури письменник вибудовував на засадах сучасної європейської культури. Від митця вимагалися актуалізація змісту твору, вміння талановито охопити філософ- 
ським поглядом день сьогоднішній, прогностично передбачити майбутнє, бо насичена новизною літературна думка давала необхідний поштовх громадському думанню, спонукала до ефективних суспільних перетворень.

У літературно-критичних працях У. Самчука висвітлено деякі теоретичні проблеми української естетики з особливим розумінням народності, образності, оптимізму, людського щастя. Вихідні принципи тлумачення мистецьких цінностей щоразу зводилися до найголовнішого - твори повинні бути насичені «вищими правдами», «вищими вольовими чинниками», тобто вони повинні належати до «великої літератури». Концепція останньої увиразнила ідею про європейську культурну приналежність української нації.

Отже, проаналізувавши окремі тези Самчукової естетичної концепції, можемо зробити окремі висновки.

1. У словосполученні «велика література» У. Самчука міститься уявлення про значимість, масштабність творів; це синонім до поняття «класика». Літературна класика є сукупністю творів першого ряду, це верх верху літератури. Вона розпізнається тільки ззовні, зі сторони, з іншої, наступної епохи. Класична література (й у цьому іiї суть) активно включена в міжепохальні стосунки.

2. Кожна епоха по-своєму переакцентовує твори минулого. Історичне життя класичних творів є неперервним процесом їх соціально-ідеологічної переакцентації. Побутування літературних творів у «великому історичному часі» (М. Бахтін) пов’язане 3 їх збагаченням, їх смисловий потенціал здатний до росту. На новому фоні класичний твір розкриває все нові й нові смислові моменти.

3. Класика, перебуваючи поза сучасністю читачів, покликана допомагати їм зрозуміти самих себе в широкій перспективі культурного життя. Вона звернена передовсім до людей «духовно осілих» (Д. Ліхачов), які цікавляться історичним минулим і причетні до нього.

4. У складі літературної класики розрізняють авторів, які мають світове значення (Гомер, А. Данте, В. Шекспір, Й. В. Гете, 
Ф. Достоєвський), і національних класиків - письменників, які мають найбільший авторитет у літературах окремих народів (Т. Шевченко, І. Франко, Леся Українка).

5. Проект соцреалізму в СРСР був проектом масової літератури, імперським продуктом, який експлуатував культурні потреби мас передусім з політичних позицій.

\section{БІБЛІОГРАФІЯ}

Барабаш 2004 - Барабаш Ю. Гоголь у літературній свідомості українського зарубіжжя: Нариси сприйняття та інтерпретацій / Ю. Барабаш // Нові гоголезнавчі студії. - Вип. 1(12). - Сімферополь : Кримський Архів, 2004. - 128 с.

Грабович 1993 - Грабович Г. У пошуках великої літератури / Г. Грабович. - К. : Інститут української археографії, 1993. - 53 с.

Павличко 1997 - Павличко С. Дискурс модернізму в українській літературі : монографія / С. Павличко. - К. : Либідь, 1997. - 360 с.

Самчук 2005 - Самчук У. Велика література. Доповідь на I з'їзді Мистецького українського руху (МУР), грудень 1945 / У. Самчук // Улас Самчук. Роздуми про літературу : збірник літературно-критичних статей / упоряд., передм., післямова М. Гона. - Рівне : ВАТ «Володимирецька районна друкарня», 2005. - С. 8-27.

Самчук 1946 - Самчук У. 3 книги битія / У. Самчук // МУР: Література. Мистецтво. Критика : альманах / Б. Подоляк (ред.). - Штуттгарт : Б. в, 1946. - Ч. 1. C. $47-58$.

Самчук 1971 - Самчук У. Ідейні мотиви моєї творчості / У. Самчук // ВРФТ ІЛ. Ф.195. - Од. зб. 144. - 42 арк.

Самчук б. д.-1 - Самчук У. Письменник і нація / У. Самчук // ВРФТ ІЛ. - Ф. 195. Од. зб. 124. -2 арк.

Самчук б. д.-2 - Самчук У. Про прозу взагалі і прозу зокрема: До проблеми нашої літературної прози / У. Самчук // Улас Самчук. Роздуми про літературу : збірник літературно-критичних статей / упоряд., прим., післямова М. Гона. Рівне : ВАТ «Володимирецька районна друкарня», 2005. - С. 28-40.

Самчук 1943-1 - Самчук У. Типи літератури, чи типи життя / У. Самчук // Документ доби: публіцистика Уласа Самчука 1941-1943 років / упоряд.

А. Жив'юка. - Рівне : ВАТ «Рівненська друкарня», 2008. - С. 343-345.

Самчук 1943-2 - Самчук У. Щось, чи що читати / У. Самчук // Документ доби: публіцистика Уласа Самчука 1941-1943 років / упоряд. А. Жив'юка. - Рівне : ВАТ «Рівненська друкарня», 2008. - С. 341-343.

Чижевський 2005 - Чижевський Д. Порівняльна історія слов'янських літератур : у 2 кн. ; пер. $з$ нім. / Д. Чижевський. - К. : ВЦ «Академія», 2005. - 288 с. 